\title{
SOCIAL REPRESENTATIONS OF THE SEXUAL LIFE OF CLIMACTERIC WOMEN ASSISTED AT PUBLIC HEALTH SERVICES ${ }^{1}$
}

\author{
Ivonete Alves de Araújo², Ana Beatriz Azevedo Queiroz ${ }^{3}$,Maria Aparecida Vasconcelos Moura4, Lúcia Helena \\ Garcia Penna ${ }^{5}$
}

${ }^{1}$ Extracted from the dissertation - As representações sociais da sexualidade da mulher no climatério: subsídios para o cuidado de enfermagem, Nursing Graduate Program at the Anna Nery School of Nursing (EEAN) at Federal University of Rio de Janeiro (UFRJ), 2009.

${ }^{2}$ Master of Nursing. RN of the Ministry of Health and the Alexandre Fleming Municipal Maternity Hospital. Rio de Janeiro, Brazil. E-mail: enfivonete@hotmail.com

${ }^{3}$ Ph.D. in Nursing. Adjunct Professor IV of the Department of Maternal-Child Nursing and the Graduate Program at EEAN/ UFRJ. Rio de Janeiro, Brazil. E-mail: anabqueiroz@oi.com.br

${ }^{4}$ Ph.D. in Nursing. Associate Professor III of the Department of Maternal-Child Nursing and the Graduate Program. Rio de Janeiro, Brazil. E-mail: maparecidavas@yahoo.com.br

${ }^{5}$ Ph.D. in Health Sciences. Adjunct Professor of the Department of Maternal-Child Nursing and the Graduate Program at the College of Nursing at the Rio de Janeiro State University. Rio de Janeiro, Brazil. Email: luciapenna@terra.com.br

\begin{abstract}
The present study aimed at studying the social representations of the sexual life of climacteric women. Its theoreticalmethodological referential was based on the Theory of Social Representations. Study participants were 40 women between 45 and 65 years of age, who were divided into two groups: perimenopause and postmenopause. Scenarios were two public units of health services for women in the municipality of Rio de Janeiro. Data were collected through the semistructured interview technique and treated according to the analysis of thematic content. Results indicated three representation fields. Two fields emerged in the perimenopause group: continuity of sensuality and sexuality, and representation of the negativity in climacteric leading to a sexual life without pleasure. The postmenopause group was organized into one representational field: sexual life based on the aging process. The authors concluded that the representations regarding sexual life in climacteric are being redesigned by some women despite many conceptions that still persist in association with traditional socio-historical-cultural values regarding women and the aging process.
\end{abstract}

DESCRIPTORS: Nursing. Women's health. Climacteric. Sexuality.

\section{REPRESENTAÇÕES SOCIAIS DA VIDA SEXUAL DE MULHERES NO CLIMATÉRIO ATENDIDAS EM SERVIÇOS PÚBLICOS DE SAÚDE}

\begin{abstract}
RESUMO: Objetiva estudar as representações sociais da vida sexual da mulher no climatério. O referencial teórico-metodológico apóia-se na Teoria das Representações Sociais. Participaram 40 mulheres entre 45 a 65 anos, divididas em dois grupos: perimenopausa e pós-menopausa. Os cenários foram duas unidades públicas de atendimento à mulher no município do Rio de Janeiro. A técnica de coleta de dados foi a entrevista semiestruturada. Os dados foram tratados segundo a análise de conteúdo temático. Os resultados apontaram três campos de representações. No grupo da perimenopausa emergiram dois campos: continuidade da sensualidade e sexualidade e representação da negatividade do climatério levando a uma vida sexual sem prazer. O grupo posmenopausa se organizou em um campo representacional: vida sexual ancorada no processo de envelhecimento. Concluiu-se que as representações sobre a vida sexual no climatério vêm sendo redesenhadas por algumas mulheres apesar de muitas concepções persistirem agregadas aos valores sociohistóricoculturais tradicionais ao feminino e ao envelhecer.
\end{abstract}

DESCRITORES: Enfermagem. Saúde da mulher. Climatério. Sexualidade.

\section{REPRESENTACIONES SOCIALES DE LA VIDA SEXUAL DE LAS MUJERES EN EL CLIMATERIO ATENTIDAS EN EL SERVICIO PÚBLICO DE SALUD}

RESUMEN: Tiene el objetivo de estudiar las representaciones sociales de la vida sexual de la mujer en el climaterio. El referencial teórico-metodológico se apoya en la Teoría de las Representaciones Sociales. Participaron 40 mujeres entre 45 a 65 años, divididas en dos grupos: perimenopausia y postmenopausia. Los escenarios fueron dos unidades públicas de atención a la mujer en el municipio del Río de Janeiro. La técnica de recolección de datos fue la entrevista semi-estructurada. Los datos fueron tratados según el análisis de contenido temático. Los resultados señalaron tres campos de representaciones. En el grupo de la perimenopausa emergieron dos campos: continuidad de la sensualidad y sexualidad y representación de la negatividad del climaterio llevando a una vida sexual sin placer. El grupo de la postmenopausa se organizó en un campo representacional: vida sexual anclada en el proceso de envejecimiento. Se concluyó que las representaciones sobre la vida sexual en el climaterio vienen siendo rediseñadas por algunas mujeres a pesar de que muchas concepciones persisten agregadas a los valores socio-histórico-culturales tradicionales a lo femenino y al envejecimiento. DESCRIPTORES: Enfermería. Salud de la mujer. Climaterio. Sexualidad. 


\section{INTRODUCTION}

The increase in longevity is a worldwide reality and consequently, the number of women who experience climacteric is quite expressive, which requires public health policies that consider women in all stages of their lives.

The current Brazilian female population is of approximately 30 million women between 35 and 65 years, which means that $32 \%$ of all women are in the age range in which climacteric occurs, and provided with the improvement in quality of life and the evolution of health resources, female life expectancy increased to 72.4 years. ${ }^{1}$

The demands to meet the needs of these women have required a perceptive and careful look from health professionals, since complaints related to climacteric are frequent. Although the National Policy of Comprehensive Women's Healthcare has among its purposes the implementation of health care to women in this period, there is still poor qualification from health professionals, lack of embracement and resolvability aimed at this part of the population. ${ }^{2}$

Climacteric is defined as a biological stage of life, rather than a pathological process that comprehends the transition between the reproductive and the non-reproductive period of a woman's life. ${ }^{3}$ It is therefore, a process marked by intense physical and emotional changes, influenced by factors associated with culture, habits, personal life and family history, and by psychological and environmental questions. In this process, menopause emerges, which is characterized as the last menstruation, around 45 to 50 years of age. ${ }^{4}$

In the face of these changes, the everyday life of climacteric women is directly influenced by these transformations. Some present difficulties to adapt, others report discreet symptoms, and there are those who are capable of living in harmony with the modifications of their physical and psychological body.

Despite climacteric being a physiological stage in women's lives, it has been comprehended as a public health issue and, as such, it has been studied, mainly by the strand of biomedical and pharmaceutical researches, emphasizing the Climacteric Syndrome. Postmenopause ovarian insufficiency has been considered an endocrinopathy, since the quantitative deficiency of specific hormones (estradiol and progesterone) has a series of pathological and peculiar consequences, leading to the need for medicalization in this period. ${ }^{3}$ In this context, scientific studies related to climacteric and sexuality are primarily aimed at Hormone Replacement Therapy/HRT. ${ }^{5}$ Considering comprehensiveness in health, it is not possible to limit climacteric and consequently the related scientific studies, to hormone and/or metabolic factors, because psychosociocultural issues have expressive influence on the life of any human being, and particularly on climacteric women.

The body transformations that are expected in this stage have an impact on self-image and on the life of women, and may trigger psychological suffering depending on the view each society has regarding the female role ${ }^{6}$. These alterations in climacteric affect the sexual life of $60 \%$ of women, which may negatively influence sexual desire and interest $t^{4}$. The question of beauty crosses the social construction of a body model, which stigmatizes those who no longer fit this standard. The ideology of beauty is connected almost exclusively to young women, as if beauty could only be found in youth.

Sexuality is innate to the human being, being re-elaborated throughout the entire life cycle through influences of social, psychological, religious, cultural and economical factors, among others. It suggests affection, love, kindness and satisfaction of instinctive needs such as contact, warmth, hugs, kisses, cuddling, besides comprehending the esthetics, genetics and the identification through the reproduction of models and performances of social roles. ${ }^{7}$

Sexual life in climacteric, as well as in all other stages, must be understood in a broader context, taking into consideration the experience and the historical, social, economical and cultural context in which the woman in inserted. Thinking of the sexual life of the human being demands understanding it as multifactorial, integrated to the network of meanings of the social group. In this sense, it is constituted of a single and personal experience, deeply marked by the culture in which each person lives.

In the face of these questions, the purpose of this study was to investigate the social representations of the sexual life of climacteric women assisted at public health services.

\section{METHOD}

This is a qualitative descriptive study, from the perspective of the Theory of Social Represen- 
tations (TSR), in the procedural strand, since the sexuality here represented by the sexual life is characterized as a socially elaborated and shared phenomenon, capable of suffering continuous and reciprocal modifications, due to the context of the social environment. The TSR has its pillars on social knowledge for its explanation, allowing the understanding of the phenomena with implications in the sexual life, in which the starting point is the representation that this group has regarding climacteric. The studies based on this perspective aim to identify the interactive links of the collective life of society, as well as the symbolic constructions in which subjects give meanings and understand the world, building a social identity. ${ }^{8}$

Moscovici proposed the existence of three dimensions on which the social representation is structured, namely attitude, information and the representation field. This study focused on the representational fields of the sexual life of women who experience climacteric in an articulated, organized and hierarchical way. The elements that constitute the representation are structured according to an internal logic, establishing among themselves relationships that determine the meaning and place occupied by these elements in the representation system. ${ }^{9}$

The subjects were 40 climacteric women who were divided into two groups, with 20 interviewees in each segment: Group A (GA) consisted of women who were in the perimenopause stage, between 45 and 55 years, and Group B (GB), in the late stage, between 55 and 65 years. Exclusion criteria applied to women who were in the first period of climacteric, classified as early stage, between 35 and 44 years, and to those who did not wish to participate in the study. The study was developed in two university health units that provide gynecological care, belonging to the public service of the municipality of Rio de Janeiro.

Data were collected for a period of six months in 2009. A form was used to survey the profile of the interviewees, besides a script for an individual semistructured interview, aimed at exploring information to learn the social representation of the sexual life of these climacteric women.

The selection of women took place in the waiting room of gynecology appointments where they were invited to participate in the study, and the interviews were previously scheduled according to the availability of date and time of the subjects. This approach occurred at a reserved location after the appointment, assuring the pri- vacy, freedom and safety of the participants. The participants signed the Free and Clarified Consent Form (FCCF), after reading it and agreeing to participate in the study. The study project was approved under protocol no. 75/08, by the Research Ethics Committee of Anna Nery Nursing School and São Francisco de Assis University Hospital, complying with the ethical principles of researches with human beings.

Data were analyzed through the method of content analysis, ${ }^{10}$ which revealed the following categories: Bad/lifeless sex; Discovery/continuity of pleasure; and Without sex, but in peace. Next, based on the assigned groups and on the contents of the interviews and categories, it was possible to organize the material and form an overall guiding line of the discourses regarding the representation of the sexual life in climacteric, culminating in three fields of social representations: Women in perimenopause - representational field of the continuity of sensuality and sexuality; Women in perimenopause - the representation of the negativity in climacteric, leading to a sexual life without pleasure; and Women in postmenopause - sexual life based on the aging process.

\section{RESULTS}

\section{Socioeconomic profile of the interviewees}

The prevalent age in GA was between 45 and 50 years $(55 \%)$, whereas in GB it was over 60 years $(55 \%)$. Education was prevalent in the form of complete elementary school in GA (40\%), whereas in GB it was incomplete $(40 \%)$. The condition of having fixed partners prevailed in both groups, with $90 \%$ in GA and $80 \%$ in GB. Regarding sexual activity, $90 \%$ of GA stated they have an active sexual life and, in GB only $60 \%$ confirmed this result. It is worth highlighting that the remaining $40 \%$ stated they no longer have sexual relations, whether because they do not have a partner anymore, because they do not want to, or due to a health issue, or a combination of all. As for being in paid employment, $70 \%$ of GA worked, and in GB only $20 \%$ mentioned this activity. This result is justified, considering that a great part of them are retired.

\section{The sexual life of women in climacteric}

Regarding the sexual life of climacteric women, three categories emerged (Table 1): Bad/ lifeless sex; Discovery/continuity of pleasure; 
and Without sex, but in peace. The first category appeared in a total of 23 discourses $(57.5 \%)$, the second category in $14(35 \%)$ and the last category in only three statements $(7.5 \%)$.

Table 1 - Sexual life in climacteric according to women assisted at public health services, Rio de Janeiro, 2009

\begin{tabular}{lcccccc}
\hline Categories & \multicolumn{2}{c}{ GA } & \multicolumn{2}{c}{ GB } & \multicolumn{2}{c}{ Total of appearance } \\
& Total & Frequency & Total & Frequency & Total & Frequency \\
\hline Bad/lifeless sex & 10 & $50 \%$ & 13 & $65 \%$ & 23 & $57.5 \%$ \\
Discovery/continuity of pleasure & 10 & $50 \%$ & 04 & $20 \%$ & 14 & $35 \%$ \\
Without sex, but in peace & - & - & 03 & $15 \%$ & 03 & $7.5 \%$ \\
\hline Total & $\mathbf{2 0}$ & $\mathbf{1 0 0} \%$ & $\mathbf{2 0}$ & $\mathbf{1 0 0 \%}$ & $\mathbf{4 0}$ & $\mathbf{1 0 0 \%}$ \\
\hline
\end{tabular}

The first category emerged from discourses of women who referred that in this period sex has no reason to exist, no purpose, no motivation, and it is even pointed out as something painful and perverse to be experienced. This category appeared in both groups, but with greater relevance in GB, in 13 statements (65\%), demonstrating that older women are more resentful of lacking a pleasant sexual life. In this context, the results showed seven (35\%) women had no sexual activity.

Before this stage I lived my sexual life normally, with pleasure, the relationships completed me. Today it is really difficult, I have vaginal desiccation, because the skin is drier. Completely different! I am getting old! If I didn't have a husband I wouldn't want a man. Sexual interest decreased (Int. 22 GB).

In my opinion climacteric means the end of life, terror, a lot of discomfort every day; and what is the use for sex? I have had children. There is no need for sex, I will not have any more children. That's all I need, an old lady having sex! (Int. 15 GB).

Problems of pressure, thyroid, obesity, horrible skin, hair loss. I feel old and sick. How can I have sex in this condition? Everything hurts (Int. 1 GB).

There are several reasons leading women to point out sex in this stage as something "lifeless/ bad", for instance the partner's lack of understanding regarding the moment experienced; the body changes, such as flaring and vaginal desiccation, but also the questions shared to the aging process, such as flab, muscle mass loss and generalized pains. Nevertheless, other external questions related to family life, such as the concern with children, health and finances, fear of adultery, and even not considering sex as appropriate to age despite feeling desire, were also pointed out by some women, with plenty of emphasis and meaning.
The sexual function does not only suffer biological changes with the age, but also due to emotional, social and cultural questions that interfere significantly in the intensity and quality of the sexual response and desire. ${ }^{3}$ It is important not to forget that aging that coincides with climacteric is seen in our society as a period of loss in relation to beauty, attractiveness and the reproductive function, a cultural synonym of the woman, which leads to the belittlement of femininity. ${ }^{2}$ If these representations are conditioned to a conception of old age as a stage of life associated with losses, it is expected that it would generate great expectation and rejection in the subject, since it is configured with what is expected from this old age. ${ }^{11}$ This fact may be comprehended, according to Moscovici, ${ }^{8}$ by referring that people are under the control of a dominant ideology that is produced and imposed by a social class, whether it is the State, Medicine or the Church, who think and reflect this ideology.

In this perspective, it is important to highlight that in the studied category, which presented 23 statements, 14 participants still maintain a sexual life in a passive way, that is, with the only purpose of meeting the man's sexual pleasure and satisfaction. These women believe that it is their function and responsibility to be at the service of their partner's desire. This representation is based on the historical cultural role of the woman who was and still is submissive in the family context, marked by patriarchal values that have characteristics such as reproduction, monogamy and durability of the union and harmony. ${ }^{12}$

Sex, in my opinion, would be better if it did not exist. It is so bad to do something you do not want to. I do it because I have to, it takes me three months or more to have a relationship. I run away as much as I can! But 
the problem is that there are other women around. So I cannot stop, I have the obligation! This is my obligation as a woman, as a wife... (Int. $29 \mathrm{~GB}$ ).

One of the reasons that must be highlighted as for the painful experience of the sexual life in this stage is the partner's position, for instance the indifference, the lack of understanding towards this stage, the rudeness and the treatment towards the woman as an object of sexual desire.

My husband doesn't prepare anything before the relation, he just comes and that's it! I can't explain if I have pleasure, I think I don't feel anything, once he is satisfied everything is over. I don't know what an orgasm is! He is not affectionate, he has never been. But as age goes by it gets worse, I think it is worse. I am telling you, I don't feel like doing anything. He comes and does what he has to do, and I just pray for it to end (Int. 26 GB).

In the statements, it is possible to observe the expression of the patriarchal culture, in which the woman is the man's object, dominated, hierarchized, and which determines a socially unequal relationship between men and women known as domination-exploitation..$^{12}$ A relationship of power that makes it clear that the man was not created to be a partner, but to command. This inequality between genders has historically made women inferior and submissive, and this is clearly reflected in the sexual scope, in the routine of the couples, and in the intimacy. And this seems to increase as age passes by. The repercussions of the woman's aging process over her sexuality constitute a subject particularly filled with prejudice and stigma, as if sexuality and pleasure were attributed only to young women due to their physical vigor and beauty. ${ }^{13}$ Women base sexuality in the climacteric on a historical sphere in which this stage may represent a turning point between sexual pleasure/desire and the purpose of this binomial. This situation may be understood through the female sexuality history, in which the woman's sexual life was socially accepted only to serve the partner and dedicated for procreation. These women traditionally present a connotation of years or a lifetime of sexual repression that permeated western societies, thus, reinforcing the ideology that sex in this age range is no longer necessary or important.

This fact was observed because this study included older women, who present a traditional system regarding sexuality and sex at a more advanced age. Besides, 12 (60\%) women in this segment were seniors, thus presenting social stereotypes of older women. When women build an understanding of climacteric without sexual motivation, they interpret and translate the social knowledge regarding this issue, which reminds them of the effects of social control in their lives. ${ }^{6}$ Through an active process, women assimilate this knowledge and relate it to themselves, and incorporate other information according to the media and resources to which they have access. Provided with this understanding, representations are elaborated based on the information that is circulated, renewed, and crystallized. ${ }^{8}$

The second category "Discovery/continuity of pleasure" consists of the statements of the interviewees who stated that sex in this stage was related to the true discovery of pleasure and orgasm or to the continuity of sexual desire. In this category the participants mentioned there was no decrease in pleasure, it was rather the opposite, as they referred that the climax of a sexual relationship was only experienced in this stage of life.

Now I feel orgasm and sexual desire for my boyfriend, everything is good with him! I will go to the moon with him! I have just discovered where the moon is! Can you believe it? [laughter] (Int. 07 GA).

Despite having put on a lot of weight, the sexual activity remains the same. The same fire and desire as usual, the companionship... (Int. 30 GB).

This discovery or even the continuity of sexual pleasure after entering climacteric was justified by several reasons such as, having more time to take care of themselves since their children had already grown-up, greater companionship, and sometimes a new sexual partner, life and financial stability; the fact of no longer worrying about the possibility of getting pregnant or menstruating, among others. All these factors bring to climacteric a greater tranquility that certainly contributed to improve the quality of the sexual relationship. This does not mean that these women do not feel body changes and symptomatologies typical of this stage, but it did not prevent them from living their sexuality more completely. These discourses show that experiencing sexuality involves an enormity of feelings, such as being with the other, feeling the other and understanding the multiple possibilities of the relationship. ${ }^{14}$

Among the confrontation possibilities, so that the changes would have less impact on the routine of these women, it is possible to highlight the participation in senior groups, new partners, changes of life habits including physical activities, and eating changes. This phenomenon may be explained by the analysis of Moscovici, ${ }^{8}$ in 
the statement that the representations are multifaceted, dynamic and fluid, renovated with time and social changes. It also highlights aging, the position of free will and greater learning in life, manifesting the plenitude of physical and psychological maturity.

I am in no rush to anything. But things are different with my husband! He does everything I want in bed. He says I am pretty and hot. I also take care of myself to be pretty for him (Int. 07 GA).

In the past I used to have more energy, that has changed, but it is better now. It is slower. My husband used to want to have sex every day. All we do is change the position; I try to vary! He is affectionate... I take good care of myself for him (Int. 11 GA).

Although several reasons are presented, one in particular deserves attention, by analyzing the discourses of this segment of women: the companionship, whether it comes from years of living together or from new relationships. These partners usually appreciate them as women, respecting their desires, praising their femininity, being present and true companions in their lives. The fact of feeling understood, loved, respected, attractive and desired awakes the desire to be closer to their partner. In these conditions, there is a greater involvement between the couple, promoting an increase in the self-esteem of the woman and, consequently, of the couple. Provided with this involvement, sexual emotional relationships tend to be well experienced and pleasant, which brings a special color to life. Women and men have the degree of affectation determined by their psyche, including their experiences, their achievements and that which they did not achieve, throughout their life history. ${ }^{15}$

Regarding the assigned groups, it was verified that this category was more present in GA, in 10 statements (50\%), whereas in GB it emerged in only four discourses $(20 \%)$. This led to the reflection that this favorable point in sexual life appeared for women in the stage of perimenopause, in which body changes are still not so emphasized, and some factors typical of old age have not yet appeared, in comparison to the women in the segment of postmenopause. As described in the profile of the participants, the women in GA generally work, some still menstruate, date, and are not considered by common opinion as elderly; they are women who feel socially productive, with physical vigor and without the presence of pathologies inherent to old age. ${ }^{15}$
It is understood that the symbols historically created between youth and old age, are produced in the public sphere and refer to intersubjective productions treated in the daily life. ${ }^{16}$ These representations are shared in the collective scenarios and start becoming, themselves, the providers of these social representations. This fact is notorious when these women express their wishes of care to experience a pleasant and satisfactory sexual relationship, whether it is with their partner of years of life together or with a new one.

The third category, "Without sex, but in peace", stood out only in GB, with three women $(15 \%)$. It consists of women who even without having sexual activity feel peaceful, since they mention they no longer have sexual desire, or the will to have a sexual life. They state they have found in other activities, such as in the participation in religious groups, senior groups, in the care of their grandchildren and family, besides the participation in courses and physical activities, among others, a greater purpose for their life. Finally, they find themselves with other plans that give them as much pleasure or even more than sex, which helps them not to feel the lack of this component. ${ }^{16}$

This behavior is impregnated with meanings, enriching the structure of what it means to each, the experienced reality and the tradition of their culture. ${ }^{17}$

My husband went to the South! I have not been feeling any problems lately, because I have so many chores of structural and family order, and I do not miss it at all. I feel really lively. My family has been my priority [...] (Int. $28 \mathrm{~GB}$ ).

I do not feel like having sex. It was good while it lasted! Now I have other priorities in life: like church. Now we are friends, companions, and we don't need sex for that! I am really happy! (Int. 36 GB).

\section{DISCUSSION}

\section{Theory on the social representations of women regarding sexual life in climacteric}

Based on this trajectory, the social representations of the study participants are presented regarding sexual life, considering that the latter suffers direct influence from the experience of climacteric/menopause. The social subject actively constructs or reconstructs their reality in an autonomous and creative way. The individuals represent by excellence, the space of the social 
subject, struggling to give meaning, interpret and construct the world in which they are. ${ }^{18}$ In the process of elaboration of these social representations, the women in this study use several mechanisms, which must be understood, in order to make known the grounding of this phenomenon, and what seems strange and challenging is transformed into something familiar and known. Based on this presupposition, the grounding process of the interviewees is discussed in order to understand the social representations of sexual life in climacteric.

From the adopted analytical procedures, it was possible to perceive the construction of three representation fields, structured in conformity with the assigned groups (GA and GB) used in this study.

\section{Representational field of continuity of sensuality and sexuality}

In this first representational field, 11 women in perimenopause participated out of the 20 interviewed. Climacteric was considered a calm stage in their lives, as although they perceive the physical and psychological changes related to this moment, they do not judge them as losses; but as a period of maturity and new achievements. This assigned group presents specific characteristics, since climacteric shows points related to moments of freedom, new discoveries, maturity and great learning, that is, they recognize it as a salutary period in their lives. In this context, sex in climacteric was represented as the continuity or discovery of pleasure, which is associated with the possibility of construction or renovation of the sexual life. Women feel desired, loved, still presenting vigor and sexual attraction, with power of sensuality and femininity, because the constitution of the subject's identity is expressed as how they experience the issue of their own corporeity and sexual emotional intimacy, significance of the group norm, morality and group ethics. The sexual expression is multidetermined, dynamic and historically represented both in the individual and in the collective. These representations common to this group of women result from similar practices and were grounded on sociocultural characteristics of contemporaneity, specific to the gender changes. Social representations defined as constitutive of the social thought are, therefore, filled with prescriptive and conventional power over reality and the social environment ${ }^{8}$, allowing to comprehend this movement of contemporane- ity. The world view of this group in relation to climacteric and its repercussion in their sexual life shows a new meaning to the female condition, restructuring the conceptions as for the climacteric woman as a being, in which sexual pleasure and desire may be points of achievement for this new female conception, no longer outlined only in motherhood and in youth.

\section{The representation of negativity in climacteric leading to a sexual life without pleasure}

This second representational field had the participation of nine women out of the 20 belonging to GA, who had diverging representations to the previous representation. For these women, climacteric was perceived with a strong context of devaluation regarding the changes that occurred in their lives at this stage. Body changes were referred, mainly, through the concerns with the loss of beauty and youth, and with the typical symptoms of the biological changes in climacteric. The negative view of sex in climacteric is, thus, also evidenced. The phenomenon here is based on the strong social correlation between sex and reproduction. The historical view of the female body as reproductive is the base to understand that the women in menopause is asexual, that is, since her maternal function is concluded, there is the connotation that it is no longer necessary to continue with a sexual life. The representations of these women regarding sex in climacteric without pleasure were constructed in the face of experiences within a social environment, influenced by the media and the cultural tradition of the female role centered in motherhood. This view of the woman is still associated with valuation principles that surround our society, referring that attractive means having a young, thin, muscular body and no wrinkles, leaving nothing but memories for the old.

\section{Sexual life based on the aging process}

In the analysis of this representational field, it is observed that the 16 interviewees in this field belong to GB. Climacteric for this group becomes singular due to the almost complete absence of positive conditionings associated with their interpretations and inferences regarding this life stage. From the perspective of the representations, it is necessary to interpret what happens to them in order to signify climacteric; these women draw on situations to which they face routinely, in order to 
guide their choices and practices as for sex in this stage. The grounding of climacteric is perceived as a process of aging and disease, in which their social roles as working women, mothers, and wives are compromised. Despite this pathologic view of climacteric, the elaboration of this representation is historically and culturally based on the medical metaphors of the woman's body, as to menstruation and menopause, with the latter being considered a female illness. ${ }^{19}$

In face of this set of knowledge of social recoveries, sex in climacteric was represented as lifeless and needless, reinforcing the symbology of sex as something merely biological and associated with life, reproduction and youth. Finally, this analysis may be better understood by emphasizing that, as a phenomenon, social representations are presented under several images and concentrated in a set of meanings that allow the explanation of what is happening. ${ }^{18}$

\section{FINAL CONSIDERATIONS}

Studying the social representations of the sexual life of climacteric women assisted at public health services, constituted a challenging intellectual enterprise due to the fact that the theme is still poorly explored, and involves complex questions in the representational field of the relationships of sensuality and sexuality in the climacteric stage, associated with the traditional socio-historicalcultural values regarding femininity and aging. The choice for a cultural line of study permitted to research the pertinent object in a dynamic, multifactorial, complex reality, which is still under transformation, and whose leading axis was a set of knowledge of social recoveries, reinforcing the symbology of sex as something merely biological and associated with life, reproduction and youth, in a comprehension of the social representations from several images that are concentrated in meanings that allow to explain what is happening. Furthermore, it was possible to understand the way these women experienced their sexuality in this period of climacteric, specifically, their sexual life. Their experiences and countless expectations, were different in each segment: for some of them, there were moments of personal appreciation, self-esteem, autonomy, discoveries, achievements, maturity and freedom; whereas for others, there were disappointments, prejudice, losses, loneliness, uncertainties and negative values.

The results indicate that the sexual life of climacteric women was based on the feminine stereotypes of a conservative cultural system, in which sex and love must walk together as something inseparable and dependent on one another. On the other hand, the view of the woman's sexual aging in climacteric reinforced the idea that there is erotic attention only in the young people's sphere, demanding the search for the discovery of other values, other than the physical for sexual attractiveness.

Climacteric still needs further investigation since it is impregnated with a culture of prejudice, fears, myths and silences subdued by a society in which women are considered submissive beings. They are unprepared to have or experience a pleasant and satisfactory sexual life, due to a Jewish-Christian religious educational process, within strict rules as for the use of their own body and sexuality.

It is necessary to learn more regarding the reality of this social group of women: their experiences and their needs, in order to build, based on the interaction and dialogue, care strategies that aim at a greater autonomy of these women towards their body, their sexuality, and, consequently, their participation in society as citizens.

\section{REFERENCES}

1. Instituto Brasileiro de Geografia e Estatística. Tábua de vida: tábua completa de mortalidade - sexo feminino [online]. Brasília (DF): IBGE; 2004 [acesso 2010 Set 30]. Disponível em: http://www.ibge. gov.br/ibge/estatistica/populacao/tabuadevida/ textomulhers2000.shtm

2. Valença CN, Nascimento Filho JM, Germano RM. Mulher no climatério: reflexões sobre desejo sexual, beleza e feminilidade. Saúde Soc [online] 2010[acesso 2012 Ago 17] 19 (2):273-85. Disponível em http:/ / www.scielo.br/pdf/sausoc/v19n2/05.pdf

3. Lima SMRR, Botogoski SR. Menopausa: o que você precisa saber - abordagem prática e atual do período do climatério. São Paulo (SP): Ed. Atheneu; 2009.

4. Ministério da Saúde (BR). Secretaria de Atenção à Saúde. Departamento de Ações Programáticas Estratégicas. Manual de atenção à mulher no climatério/menopausa. Brasília (DF): MS; 2008.

5. Araújo IA. As representações sociais da sexualidade da mulher no climatério: subsídios para o cuidado de enfermagem [dissertação]. Rio de Janeiro (RJ): Universidade Federal do Rio de Janeiro, Escola de Enfermagem Ana Nery; 2009.

6. Oliveira DM, Jesus MCP, Merighi MAB. Climatério e sexualidade: a compreensão dessa interface por mulheres assistidas em grupo. Texto Contexto Enferm. 2008 Jul-Set; 17 (3):519-526. 
7. Silva RM, Araújo CB, Silva ARV. Alterações biopsicossociais da mulher no climatério. Rev Bras Promo Saúde. 2003 Jul-Ago; 16(1/2):28-33.

8. Moscovici S. Representações: investigações em psicologia social. Petrópolis (RJ): Editora Vozes, 2003.

9. Jodelet D. Representações sociais: um domínio in expansão. In: Jodelet D, organizadora. As representações sociais. Rio de Janeiro (RJ): Ed UERJ; 2001. p. 17-44.

10. Bardin L. Análise de conteúdo. Lisboa (PT): Ed Setenta; 2010.

11. Cruz RC, Ferreira MA. Um certo jeito de ser velho: representações sociais da velhice por familiares de idosos. Texto Contexto Enferm. 2011 Jul-Set; 20(1):144-51.

12. Del Priori M. História do amor no Brasil. $2^{a}$ Ed. São Paulo (SP): Contexto, 2006.

13. Del Nero U. Alterações orgânicas no climatério/ menopausa que repercutem sobre a sexualidade feminina. Femina. 2006, 16(4):164-7.

14. Gonçalves R, Merighi MAB. Reflexões sobre a sexualidade durante a vivência do climatério Rev Latino-am Enfermagem. 2009 Mar-Abr; 17(2):160-6.

15. Zampieri MFM, Tavares CMA, Hames MLC, Falcon GS, Silva AL, Gonçalves LT. O processo de viver e ser saudável da mulher no climatério. Esc Anna Nery Rev Enferm [online]. 200 [acesso 2011 Ago 20]; 13(2):305-12. Disponível em: http:/ / www.eean.ufrj. br/revista_enf/20092/artigo\%208.pdf

16. Martín Casado AM. La sexualidad femenina durante el climaterio: representaciones, símbolos y estereótipos. Metas Enferm. 2010 Abr; 13(3):50-5.

17. JovchelovitchS. Cultura e pesquisa em representações sociais: saberes sociais e polifasia cognitiva. Blumenau (SC): PPGE; 2001.

18. Jodelet D. Loucura e representações sociais. Petrópolis (RJ): Vozes; 2005.

19. Matos MIS, Soihet R. O corpo feminino em debate. São Paulo (SP): Ed. Unesp; 2003. 